\title{
Capsules of the diatom Achnanthidium minutissimum arise from fibrillar precursors and foster attachment of bacteria
}

Katrin Leinweber, Peter G Kroth

Achnanthidium minutissimum is a benthic freshwater diatom that forms biofilms on submerged surfaces in aquatic environments. Within these biofilms, $A$. minutissimum cells produce extracellular structures which facilitate substrate adhesion, such as stalks and capsules. Both consist of extracellular polymeric substance (EPS), but the microstructure and development stages of the capsules are so far unknown, despite a number of hypotheses about their function, including attachment and protection. We coupled scanning electron microscopy (SEM) to bright-field microscopy (BFM) and found that $A$. minutissimum capsules mostly possess an unstructured surface. However, capsule material that was mechanically stressed by being stretched between or around cells displayed fibrillar substructures. Fibrils were also found on the frustules of nonencapsulated cells, implicating that $A$. minutissimum capsules may develop from fibrillar precursors. Energy-dispersive X-ray (EDX) spectroscopy revealed that the capsule material doesn't contain silicon, distinguishing it from the frustule material. We furthermore show that bacteria preferentially attach to capsules, instead of non-encapsulated $A$. minutissimum cells, which supports the idea that capsules mediate diatom-bacteria interactions. 


\section{Authors}

\section{Katrin Leinweber* and Peter G. Kroth ${ }^{*}$}

$3 *$ * Biology Department, University of Konstanz, Germany

4 corresponding author:

5 Katrin Leinweber

$6 \quad$ Universität Konstanz

7 Postbox/Fach 611

$8 \quad 78457$ Konstanz

9 Germany

$10 \quad 00497531882782$

11 katrin.leinweber@uni-konstanz.de 


\section{Introduction}

13 Diatoms (Bacillariophyceae) are among the most productive photoautotrophic, aquatic

14 microorganisms. They contribute an estimated $40-45 \%$ to the net primary production (NPP) of

15 the oceans (Mann, 1999), which themselves contribute approx. 45-50\% to the global NPP (Field

16 et al., 1998). Additionally, diatoms are important for the biogeochemical cycling of silicon, due to

17 their ornate cell walls (called "frustules") composed of biomineralised silica (Bradbury, 2004).

18 Cell division includes the separation of the two frustule parts ("thecae") along a "girdle" region.

19 Each daughter cell then complements its inherited epitheca with a newly synthesised, smaller

20 hypotheca. Within these thecae, slits (called "raphes") and pores may be present, facilitating the

21 secretion of extracellular polymeric substances (EPS; Wetherbee et al., 1998; Wang et al., 2000).

22 This in turn conveys substrate attachment and motility to benthic diatoms, which often form

23 biofilms with other photoautotrophic algae, as well as heterotrophic bacteria (Buhmann, Kroth \&

24 Schleheck, 2012).

25 The diatom Achnanthidium minutissimum (Kützing) Czarnecki (1994) is a cosmopolitan

26 freshwater diatom (Round \& Bukhtiyarova, 1996) that is also found in the littoral zone of Lake

27 Constance. It represents a dominant species complex of early colonisers (Johnson, Tuchman \&

28 Peterson, 1997), forming epilithic biofilms in association with a variety of satellite bacteria

29 (Bahulikar, 2006). Such bacteria as well as their spent media have been shown to increase the

30 secretion of extracellular polymeric substances (EPS) like carbohydrates by A. minutissimum

31 (Bruckner et al., 2011). Additionally, growth as well as secretion of proteins and dissolved free

32 amino acids was reportedly influenced in presence of bacteria (Bruckner et al., 2008, 2011).

33 Analogous to the rhizosphere of terrestrial environments (composed largely of fungi and bacteria

34 associated with plant roots), a "phycosphere" has been defined as the space surrounding algal

35 cells including the multitude of inter-kingdom interactions between bacteria and algae (Bell,

36 Lang \& Mitchell, 1974; Amin, Parker \& Armbrust, 2012).

37 EPS secretion is of ecological relevance, contributing for instance to the stabilisation of

38 sediments (Cyr \& Morton, 2006; Lubarsky et al., 2010). Studying biofilm formation can

39 therefore assist in the understanding of shore and coastline erosion as a result of climate-related

40 changes (see section 3.2.1 of Widdows \& Brinsley, 2002 plus references therein). At the same

41 time diatom settlement is one of the major causes of biofouling of man-made machinery in

42 aquatic applications (Molino \& Wetherbee, 2008). 
A. minutissimum is an excellent model for studying diatom biofilms, because this alga is abundant in natura (Patrick \& Reimer, 1966; Krammer \& Lange-Bertalot, 1991) and can be cultivated in the laboratory both as "xenic" biofilms (Myklestad et al., 1989) and "axenic" suspension cultures (Windler et al., 2015). Xenic cultures contain bacteria from the diatom's natural habitat. Removal of these bacteria is possible (for example by antibiotic treatment) and yields viable axenic cultures (Bruckner \& Kroth, 2009; Windler, Gruber \& Kroth, 2012). Bacteria-free cultures allow the establishment of bioassays in order to study the interactions between diatoms and bacteria, although potentially unwelcome long-term effects have to be taken into account. For example, axenic cultivation can lead to a reduction of average cell size and to frustule deformations (MacDonald, 1869; Pfitzer, 1871; Geitler, 1932; Windler et al., 2014b). However, such deformations also occur naturally and can be used as stress markers, as well as water quality indicators (Morin, Coste \& Hamilton, 2008; Falasco et al., 2009; Cantonati et al., 2014).

\section{A. minutissimum forms biofilms and extracellular structures like stalks and capsules. These} structures have been defined as "unidirectionally deposited, multi-layered structures attaching cells to substrata" (Hoagland et al., 1993). Stalks have been investigated previously by transmission electron microscopy and biochemical techniques to elucidate structural morphology and chemical composition (Daniel, Chamberlain \& Jones, 1987). Additionally, a phase model of diatom adhesion involving stalks has been developed (Wang et al., 1997): Stalks may protrude from so called "basal pads" of aggregated EPS at the apical valve faces within hours to a few days, thus elevating the cells above the substrate. Capsule formation in A. minutissimum biofilms occurs later in the stationary phase, is possibly triggered by bacterial influences, and may cement diatom attachment (Windler et al., 2015). That study also found that axenic A. minutissimum cultures mostly secrete soluble carbohydrates while the insoluble carbohydrates in xenic cultures were positively correlated with the appearance of capsules.

Diatom capsules have puzzled phycologists for a long time and their potential physiological and ecological function have elicited a variety of hypotheses (Lewin, 1955; Geitler, 1977). For example, capsules have been proposed to participate in locomotion, flotation, attachment, waste removal, catchment of inorganic nutrients, storage of polysaccharides, sexual reproduction, as well as protection against grazing and dehydration. More recently, it was demonstrated that capsule formation is dependent on at least "a certain minimum light intensity", sparking the idea 
74 that capsules might serve as an additional polysaccharide storage pool, once intracellular

75 capacities are saturated (Staats et al., 2000).

76 Diatom capsules and other extracellular material have been characterised biochemically, while 77 electron microscopy has enabled highly detailed morphological characterisations of diatom 78 frustules (Toyoda et al., 2005, 2006; Morin, Coste \& Hamilton, 2008). Additionally, atomic force microscopy (AFM) revealed many mechanical properties of the extracellular polymers of some diatoms (Crawford et al., 2001; Higgins et al., 2003; Willis et al., 2013). In the present study, scanning electron microscopy (SEM), as well as energy-dispersive X-ray (EDX) spectroscopy were employed to analyse the microstructure and development stages of Achnanthidium minutissimum capsules in order to further develop this species as a model system for diatom-bacteria interactions, and to elucidate one aspect of the complex interactions of diatoms and other microorganisms.

\section{Materials and Methods}

\section{Cultivation conditions}

Achnanthidium minutissimum (Kützing) Czarnecki (1994) was isolated from photoautotrophic epilithic biofilms of Lake Constance as previously described (Windler, Gruber \& Kroth, 2012). Stock cultures were grown in cell culture flasks with ventilation caps (Sarstedt, Newton USA) filled with modified liquid Bacillariophycean Medium (BM; Schlösser, 1994; Windler, Gruber \& Kroth, 2012) in two different culture states: either with co-isolated bacteria ("xenic"), or "axenic" after their removal (Windler, Gruber \& Kroth, 2012). Monthly, these stock cultures were scraped off the flask bases and sub-cultured in new BM.

Biofilms were grown directly on SEM sample carriers by the following procedure: Sample carrier disks of ca. $1 \mathrm{~cm}$ in diameter were punched from Thermanox tissue culture cover slips (Miles Laboratories Inc., USA). Thermanox material has two different sides, therefore care was taken to always store and handle the disks right-side-up. They were sterilised by immersion in $70 \%$ isopropanol ( $/ / \mathrm{v}$ in $\left.\mathrm{H}_{2} \mathrm{O}\right)$ over night and subsequently irradiated with UV light for $2 \mathrm{~h}$ in a laminar flow cabinet. One sterile disk was placed into each well of 6-well plates (Sarstedt, USA, order number 83.1839.500) and covered with 3 to $5 \mathrm{~mL} \mathrm{BM}$. Culture wells were inoculated with $5 \times 10^{5}$ to $1 \times 10^{6} \mathrm{~A}$. minutissimum cells from the stock cultures after those were checked to be 
104 BX51 (Olympus, USA) bright-field fluorescence microscope using GFP fluorescence filters. Well

105 plates were sealed with Parafilm and incubated at $16^{\circ} \mathrm{C}$ under an illumination regime of $12 \mathrm{~h}$ dark 106 and $12 \mathrm{~h}$ light at $20-50 \mu \mathrm{mol}$ photons $\times \mathrm{m}^{-2} \times \mathrm{s}^{-1}$ for 11 to 31 days.

\section{Crystal violet staining and bright-field microscopy}

108 Thermanox disks were removed from stationary cultures after 11 to 31 days with inverted 109 ("soldering" or "cover glass") forceps (Hammacher, Germany) and rinsed with $1 \mathrm{~mL}$ sterile110 filtered tap water. A Gram-staining protocol adapted from Kaplan \& Fine (2002) was applied to 111 visualise adherent cells and their extracellular polymeric structures as follows: A droplet of $112200 \mu \mathrm{L}$ solution of $0.02 \%$ crystal violet (CV) in sterile filtered tap water was applied onto the 113 disk for 1-2 min, which was held suspended by forceps. Disks were rinsed with 1 to $3 \mathrm{~mL}$ water,

114 until the runoff no longer contained visible CV. In order to find the same cell clusters in both 115 microscopic approaches, pointing or encircling scratches were made into disk surfaces.

116 Disks were placed on moistened glass slides and moistened additionally with $20 \mu \mathrm{L}$ sterile-

117 filtered tap water. Cover slips were applied carefully and marked regions were observed under a

118 BX51 (Olympus, USA) bright-field fluorescence microscope using chlorophyll fluorescence

119 filters. Images of these areas at various magnifications were taken with AxioCams MRm

120 (fluorescence and grey-scale images) and MRc (colour) using AxioVision software (Zeiss,

121 Germany).

\section{Scanning electron microscopy (SEM) and energy-dispersive X-ray}

123 (EDX) spectroscopy

124 Diatom cells were fixed on Thermanox disks by incubation in a mixture of $2 \%$ glutaraldehyde,

$12510 \mathrm{mM} \mathrm{CaCl}_{2}$ and $10 \mathrm{mM} \mathrm{MgCl}_{2}$ in $0.1 \mathrm{M}$ sodium cacodylate buffer at $\mathrm{pH} 7$ and room

126 temperature (RT) for $2 \mathrm{~h}$. Dehydration was conducted first with $30 \%$ and $50 \% \mathrm{EtOH}$, at RT for

$1272 \mathrm{~h}$ each, followed by $70 \% \mathrm{EtOH}$ at $4^{\circ} \mathrm{C}$ over night, $90 \% \mathrm{EtOH}$ at $\mathrm{RT}$ for $2 \mathrm{~h}$ and finally with

$12896 \%$ and $100 \% \mathrm{EtOH}$ twice for $1 \mathrm{~h}$ each. Critical point drying in $\mathrm{CO}_{2}$ followed (Balzers CPD030,

129 Liechtenstein) and samples were finally sputtered with gold $(\mathrm{Au})$ and palladium $(\mathrm{Pd})$ to a

130 thickness of $5 \mathrm{~nm}$ (Balzers SCD030, Liechtenstein).

131 After fixation, dehydration and $\mathrm{Au} / \mathrm{Pd}$-sputtering, the biofilm-covered Thermanox disks were 132 imaged with a Zeiss "AURIGA" scanning electron microscope, controlled with the "SmartSEM"

133 software v05.04.05.00. The elemental composition of samples was analysed by energy-dispersive 
$134 \mathrm{X}$-ray (EDX) spectroscopy. Samples were excited with the AURIGA's electron beam at $10 \mathrm{kV}$

135 and the emitted X-rays (of specific energy levels due to the elemental electron configuration)

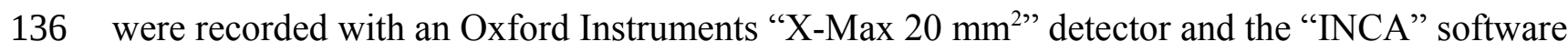

$137 \quad \mathrm{v} 4.15$.

\section{Bacteria counting and data visualisation}

139 Bacteria (rod-shaped particles) on fully visible A. minutissimum valve faces were counted in

140 scanning electron micrographs. Valve faces were classified into frustules and capsules, depending

141 on whether pores were visible or completely disappeared under a layer of capsule material.

142 Diatom cells with partial encapsulation were not included in the counting, and neither were

143 bacteria cells which attached to the girdle bands of diatom cells.

144 ImageJ v1.46r with the Cell Counter plug-in v2010/12/07 was used to count diatoms and

145 bacteria cells. This data was evaluated and visualised with R v3.1.1 (language and environment

146 for statistical computing; R Development Core Team, 2011), ggplot2 v1.0.0 (Wickham, 2009)

147 and RStudio v0.98 Desktop Open Source Edition.

\section{Results and Discussion}

For LM and SEM observations, we cultured Achnanthidium minutissimum xenically and axenically on Thermanox disks. After incubation periods of 11 to 31 days, the disk surfaces in xenic cultures were densely covered by a mono-layer of A. minutissimum cells (Fig. 1). This biofilm was visible by eye as a light greenish-brown coloration on the substrate disks after removal from the medium. Staining with the dye crystal violet (CV) and subsequent bright-field microscopy showed that large portions of the diatom cells were surrounded by capsules.

In contrast, axenic A. minutissimum cells did not form biofilms, so that even careful rinsing left much fewer cells attached to the disks and thus available for SEM analysis. This observation is in agreement with studies that utilised other growth substrates to compare biofilm formation by axenic and xenic diatom cultures. By measuring chlorophyll (chl) contents, the possibility that axenic cells might simply be less proliferate was excluded (Windler et al., 2015). Xenic A. minutissimum cultures on the other hand have also been found to develop biofilms on glass beads as well as in plastic multi-well plates (Lubarsky et al., 2010; Windler et al., 2015). Our results demonstrate, that xenic biofilms of $A$. minutissimum can also be grown on Thermanox disks, enabling direct preparation for electron microscopy of native biofilm samples. 
164 Identification of $\boldsymbol{A}$. minutissimum capsule microstructures

165 In order to correlate the hydrated A. minutissimum capsules visible in light microscopy to their

166 dehydrated appearance in SEM, areas were marked by scratches on the crystal violet (CV)

167 stained disks and cells of interest were identified by bright-field microscopy (BFM).

168 Subsequently, the same areas and cells were found again in the scanning electron microscope

169 (SEM; Fig. 2). The same technique was successfully applied to axenic cultures, despite the lower 170 prevalence of adherent cells (Supplemental Figure 1).

171 In BFM, the CV stained capsules were visible as voluminous, rounded structures around most

172 of the cells. As extracellular polymeric structures in the genus Achnanthidium are composed

173 mostly of carbohydrates (Wustman et al., 1998; Windler et al., 2015), strong hydration in the

174 native biofilm is likely the source of this appearance of capsules. In SEM, however, we were able

175 to distinguish two types of $A$. minutissimum cells in xenic biofilms already at low magnifications:

176 cells with pores in their frustules still visible, and cells covered by an apparently unstructured

177 material masking the pores.

178 The frustules of non-encapsulated xenic, as well as axenic A. minutissimum cells appeared

179 identical to those from scanning electron micrographs shown in previous studies (Mayama \&

180 Kobayasi, 1989; Potapova \& Hamilton, 2007; Hlúbiková, Ector \& Hoffmann, 2011). The low

181 prevalence of raphes in our images is most likely due to their orientation towards the substrate for

182 mucilage secretion (Gordon \& Drum, 1970; Wetherbee et al., 1998). Natural attachment and

183 orientation of cells on our biofilm disks was retained because we did not employ harsh

184 preparation techniques, such as boiling the diatom cells in sulphuric acid (Mayama \& Kobayasi,

185 1989). Such harsh treatments are designed to prepare only frustules and in our case would likely

186 have resulted in cell detachment from the growth substrate, as well as random orientation on the

187 SEM sample carrier. Instead, we utilised the SEM sample carrier disks directly as growth

188 substrates for the biofilms.

189 The SEM images in figure 3 show that the capsule material appears to be unstructured,

190 resembling the "adhering film and tube" of Cymbella microcephala and Cymbella prostrata

191 reported in figures 31 and 32 of Hoagland et al. (1993).

192 The dehydrated capsule material appeared slightly granular in scanning electron micrographs

193 (Fig. 3C), but unlike on frustules (with or without fibrils) few distinct features were apparent in

194 the capsule material. However, it appears to be similar to the shaft ultra-structure of the marine

195 diatom Achnanthes longipes displayed in figure 8 of Wang et al. (2000). 
In addition to covering the cells, the capsule material also had sheet-like structures (arrows in

197 figure 3A) where it was stretched between $A$. minutissimum cells and the anchoring points on the

198 substrate. This pattern is most likely due to dehydration during SEM sample preparation

199 (Hoagland et al., 1993). Due to fixation of the samples prior to drying, the hydrated capsules

200 most likely shrank in their entirety to the dehydrated, envelope-like structures.

201 Fibrillar precursors may give rise to A. minutissimum capsules

202 Closer inspection provided many examples that the frustules of non-encapsulated xenic

203 A. minutissimum cells were not completely free of extracellular polymeric substances (EPS).

204 Instead, they were covered by a mesh of fibrils (Fig. 3B), arranged mostly around the frustule

205 pores, sometimes crossing them and sometimes sticking out. The average diameter of these fibrils

206 was about $45 \pm 9 \mathrm{~nm}$. The fibrils were rarely observed to be secreted through the pores, although

207 these were found to be large enough (from 60 to $140 \mathrm{~nm}$ in diameter), showing round to elongated

208 shapes. Fibrils were generally longer than the diameter of pores, but quantification was not

209 performed because branching and interweaving of the fibrils made it impossible to determine the

210 respective beginnings or ends. To the best of our knowledge, this is the first report of frustule-

211 attached fibril structures in freshwater diatoms. Similarly structured, thinner fibrils were reported

212 previously only for marine diatoms (Bosak et al., 2012).

213 Fibrillar meshes of varying densities were detected in both axenic and xenic cultures, but only

214 the latter also contained capsules. Axenic cultures appeared to contain more cells with few, short

215 fibrils (Supplemental Figure 2), which may initiate surface attachment of cells in both culture

216 types. However, only in xenic cultures, bacteria could induce the secretion of firmer EPS

217 structures (Bruckner et al., 2011), and thus substrate adhesion, in the majority of cells.

218 Furthermore, we found intermediate stages between the fibrillar meshes that only partially

219 covered the frustule surface and the complete encapsulation with apparently unstructured material

220 (Fig. 4). The similarity in surface structure suggests a relation of fibrils and capsules. The

221 disordered arrangement of fibrils shown in figure 4A and $\mathrm{B}$ is also a feature of the unstructured

222 capsule material shown in figure 4C. In it, no particular order of the slightly granular

223 substructures is discernible either. This visual impression suggests that the fibrillar meshes on

224 A. minutissimum cells might be precursors to capsules, into which they may condense. An

225 alternative explanation for the capsule structure may be the polymerisation of a secondary type of

226 fibrils upon the primary mesh (Fig. 4A), relegating the latter to a scaffolding function. 
In either case, the process is not strictly synchronised between cells in the same culture. It

228

229

230

231

232

233

234

235

236

237

238

239

240

241

242

243

244

245

246

247

248

249

250

251

252

253

254

255

256

257

rather appears to be a function of each cell's individual age, because different stages appear both on days 11 and 31 of incubation, as well as in between.

To further elucidate whether or not fibrils and capsules might be related, we analysed mechanically stressed capsule areas (Fig. 5). Here, tension yielded an alignment of capsule microstructures, as well as fraying on the edges. Fibrillar structures resulting from these processes were similar in diameter to the frustule-covering fibrils.

There are two possible sources for the mechanical force. Firstly, motility of the cells relative to each other in the native biofilm. However, it has been reported for a related species in the order Achnanthales, that motility is lost upon production of EPS structures (Wang et al., 1997).

Secondly, mechanical force could be caused by the dehydration during SEM sample preparation. Both explanations lead to the question why mechanical force highlighted the fibrillar microstructure, while relaxed capsule areas (see previous figures) appeared unstructured. Micromanipulation experiments may be required to further investigate the properties of A. minutissimum capsules and their fibrillar microstructures. Such experiments have been conducted by force-mode AFM on the mucilage layers of other diatoms (Higgins et al., 2003; Willis et al., 2013).

Based on thi data, we suggest fibrils as a precursor candidate for capsules. Fibrils may condense into the capsule material as depicted in figure 4 , for example by enzymatic crosslinking or transglycosylase activity. Fibrils may be disguised in relaxed capsule material because they are arranged in a disorderly fashion, but mechanical stress yielded a visible alignment.

\section{Capsule material does not contain silicon}

Silicon ( $\mathrm{Si}$ ) is a major component of diatom frustules, in which it is present as hydrated silicon dioxide. Capsules on the other hand may consist mostly of extracellular polymeric carbohydrates (Wustman et al., 1998; Windler et al., 2015). In order to exclude the possibility that the capsule material we observed might represent frustule deformations or extensions (Windler et al., 2014b; Cantonati et al., 2014) it was screened for the presence of Si. Energy-dispersive X-ray (EDX) spectra were recorded from capsule areas with and without a cell body and thus frustule below them (Fig. 6).

As expected, higher counts around $1.75 \mathrm{keV}$, which signifies Si (Guerra et al., 2013;

Chandrasekaran et al., 2014), were obtained from capsule material, than from cell bodies. 
258 Background level Si counts are likely result from the frustule edges close- by due to the "pear 259 effect" (Arnould \& Hild, 2007). It explains, how excited electrons diffuse into the sample, so that 260 a pear-shaped volume of ca. 0.5-1 $\mu \mathrm{m}$ diameter below the measurement point or area also emits 261 detectable X-rays. The cell bodies in this figure are separated by approximately that distance. The 262 stronger gold $(\mathrm{Au})$ signal of the capsule material around $2.15 \mathrm{keV}$ compared to the control areas

263 probably resulted from the larger sputtered surface area within the measurement volume. Due to 264 the absence of notable Si signals from A. minutissimum capsule material, we can exclude the 265 possibility that it is some kind of frustule extension or deformation.

266 Furthermore, we can tentatively exclude chitin as a major component of the capsule material, 267 because no notable nitrogen signals $(\mathrm{N} ; 0.39 \mathrm{keV})$ were recorded from it. Chitin fibrils have been

268 found to be secreted by diatoms into the surrounding water body (Gardner \& Blackwell, 1971;

269 Herth, 1979). In contrast, the fibrillar meshes we describe here, tightly covered the frustule

270 surfaces of individual A. minutissimum cells and therefore likely represent different EPS

271 structures.

\section{Bacteria preferentially attach to encapsulated diatom cells}

273 It became apparent during the SEM observations, that diatom-attached bacteria cells occurred 274 more often on capsules than on frustules. To substantiate this observation, bacteria cells were 275 counted on both diatom cell surface types (Fig. 7).

276 Notably higher numbers of bacteria (ca. 25 times more on average) adhered to capsules than to 277 frustules throughout the stationary phase (means: $11.41 \pm 8.23$ and $0.46 \pm 0.82$ respectively). The 278 variance in the numbers of bacteria per diatom was larger (ca. 100 times) on encapsulated cells than on frustules, indicating that not all encapsulated A. minutissimum cells were equally strongly colonised by bacteria. Presumably, this is due to the population dynamics of the co-isolated bacteria within different areas of the xenic biofilms.

Bacteria, as well as diatom cells with only fibrillar meshes on their frustule were found to individually retain attachment to the substrate. We deem it unlikely that attachment to each other could have been too weak to withstand the rinsing step. Instead, the bacteria preferentially adhered to capsules, while either being actively repelled from non-encapsulated A. minutissimum cells or only not especially drawn to their frustules.

It has been proposed that A. minutissimum capsules might be an asset in the mutualistic 
suggest a pattern of bacterial adherence to A. minutissimum cells in xenic biofilms that would

290 support this hypothesis (Windler, Gruber \& Kroth, 2012): diatom cells were surrounded by a

291 bacteria-free space, followed by a layer of densely aggregated bacteria cells. Although no CV

292 stains were conducted in that study, the bacteria free regions resemble the EPS structures reported

293 since then as capsules.

294 In bacterial biofilms, nutrient distribution is predominantly determined by diffusion,

295 sometimes along strong gradients within a biofilm (Stewart, 2003). Similarly, variations of

296 cellular nutrient distributions within freshwater diatom biofilms exist (Murdock et al., 2010).

297 Furthermore, it is possible that diatom capsules serve as a common nutrient pool to the satellite

298 bacteria in a mutualistic relationship (Bruckner et al., 2008). Therefore, competition between

299 individual diatom cells for re-mineralising bacteria could occur. Nutrient-limited, but still

300 photosynthetically active diatom cells may produce predominantly insoluble carbohydrates to

301 foster close attachment of heterotrophic bacteria that re-mineralise EPS or secrete vitamins.

302 Our finding that bacteria attach preferentially to capsules strengthens the argument that

303 capsules play a role in the inter-kingdom relationship of satellite bacteria and benthic diatoms.

304 Whether this relationship is antagonistic, mutualistic or commensal in nature remains to be

305 elucidated. Labelling experiments with isotopes or fluorophores may assist in the determination

306 of carbohydrate fluxes from the diatom's EPS structures to bacteria feeding on those.

\section{Acknowledgements}

308 We thank Joachim Hentschel, Lauretta Nejedli and Michael Laumann of the Electron

309 Microscopy Center of the University of Konstanz for sample preparation, SEM and EDX device

310 operations, and insightful discussions, as well as Ansgar Gruber and Carolina Rio Bartulos for

311 helpful ideas and suggestions. Our gratitude also belongs to two anonymous reviewers whose

312 valuable suggestions improved this manuscript greatly.

\section{References}

Amin SA, Parker MS, Armbrust EV. 2012. Interactions between Diatoms and Bacteria. Microbiology and Molecular Biology Reviews 76:667-684.

Arnould O, Hild F. 2007. On the measurement by EDX of diffusion profiles of $\mathrm{Ni} / \mathrm{Cu}$ assemblies. arXiv:0712.3636 [physics].

Bahulikar RA. 2006. Diatoms from littoral zone of Lake Constance: diversity, phylogeny, extracellular polysaccharides and bacterial associations. 
Bell WH, Lang JM, Mitchell R. 1974. Selective stimulation of marine bacteria by algal extracellular products. Limnology and Oceanography 19:833-839.

Bosak S, Pletikapić G, Hozić A, Svetličić V, Sarno D, Viličić D. 2012. A Novel Type of Colony Formation in Marine Planktonic Diatoms Revealed by Atomic Force Microscopy. PLoS ONE 7:e44851.

Bradbury J. 2004. Nature's Nanotechnologists: Unveiling the Secrets of Diatoms. PLoS Biol 2:e306.

Bruckner CG, Bahulikar R, Rahalkar M, Schink B, Kroth PG. 2008. Bacteria Associated with Benthic Diatoms from Lake Constance: Phylogeny and Influences on Diatom Growth and Secretion of Extracellular Polymeric Substances. Applied and Environmental Microbiology 74:7740-7749.

Bruckner CG, Rehm C, Grossart H, Kroth PG. 2011. Growth and release of extracellular organic compounds by benthic diatoms depend on interactions with bacteria. Environmental Microbiology 13:1052-1063.

Bruckner CG, Kroth PG. 2009. Protocols for the Removal of Bacteria from Freshwater Benthic Diatom Cultures. Journal of Phycology 45:981-986.

Buhmann M, Kroth PG, Schleheck D. 2012. Photoautotrophic-heterotrophic biofilm communities: a laboratory incubator designed for growing axenic diatoms and bacteria in defined mixed-species biofilms. Environmental Microbiology Reports 4:133-140.

Cantonati M, Angeli N, Virtanen L, Wojtal AZ, Gabrieli J, Falasco E, Lavoie I, Morin S, Marchetto A, Fortin C, Smirnova S. 2014. Achnanthidium minutissimum (Bacillariophyta) valve deformities as indicators of metal enrichment in diverse widely-distributed freshwater habitats. Science of The Total Environment 475:201-215.

Chandrasekaran S, Sweetman MJ, Kant K, Skinner W, Losic D, Nann T, Voelcker NH. 2014. Silicon diatom frustules as nanostructured photoelectrodes. Chemical Communications 50:10441-10444.

Crawford SA, Higgins MJ, Mulvaney P, Wetherbee R. 2001. Nanostructure of the Diatom Frustule as Revealed by Atomic Force and Scanning Electron Microscopy. Journal of Phycology 37:543-554.

Cyr H, Morton KE. 2006. Distribution of biofilm exopolymeric substances in littoral sediments of Canadian Shield lakes: the effects of light and substrate. Canadian Journal of Fisheries and Aquatic Sciences 63:1763-1776.

Czarnecki DB. 1994. The freshwater diatoms culture collection at Loras College, Dubuque, Iowa. In: Proceedings of the 11th International Diatom Symposium. International Diatom Symposium. Memoirs of the California Academy of Sciences, 157.

Czarnecki DB, Edlund MB. 1995. Combinations for Some Taxa of Achnanthes. Diatom Research 10:207-209.

Daniel GF, Chamberlain AHL, Jones EBG. 1987. Cytochemical and electron microscopical observations on the adhesive materials of marine fouling diatoms. British Phycological Journal 22:101-118.

Falasco E, Bona F, Ginepro M, Hoffmann L, Ector L. 2009. Morphological abnormalities of diatom silica walls in relation to heavy metal contamination and artificial growth 
conditions. Water SA 35:595-606.

Field CB, Behrenfeld MJ, Randerson JT, Falkowski P. 1998. Primary Production of the Biosphere: Integrating Terrestrial and Oceanic Components. Science 281:237-240.

Gardner KH, Blackwell J. 1971. The substructure of crystalline cellulose and chitin microfibrils. Journal of Polymer Science Part C: Polymer Symposia 36:327-340.

Geitler L. 1932. Der Formwechsel der pennaten Diatomeen (Kieselalgen). Archiv für Protistenkunde 78:1-226.

Geitler L. 1977. Entwicklungsgeschichtliche Eigentümlichkeiten einiger Achnanthes-Arten (Diatomeae). Plant Systematics and Evolution 126:377-392.

Gordon R, Drum RW. 1970. A Capillarity Mechanism for Diatom Gliding Locomotion. Proceedings of the National Academy of Sciences 67:338-344.

Guerra MBB, Schaefer CEGR, Carvalho GGA de, Souza PF de, Júnior DS, Nunes LC, Krug FJ. 2013. Evaluation of micro-energy dispersive X-ray fluorescence spectrometry for the analysis of plant materials. Journal of Analytical Atomic Spectrometry 28:1096-1101.

Herth W. 1979. The site of $\beta$-chitin fibril formation in centric diatoms. II. The chitin-forming cytoplasmic structures. Journal of Ultrastructure Research 68:16-27.

Higgins MJ, Sader JE, Mulvaney P, Wetherbee R. 2003. Probing the Surface of Living Diatoms with Atomic Force Microscopy: The Nanostructure and Nanomechanical Properties of the Mucilage Layer. Journal of Phycology 39:722-734.

Hlúbiková D, Ector L, Hoffmann L. 2011. Examination of the type material of some diatom species related to Achnanthidium minutissimum (Kütz.) Czarn. (Bacillariophyceae). Algological Studies 136:19-43.

Hoagland KD, Rosowski JR, Gretz MR, Roemer SC. 1993. Diatom Extracellular Polymeric Substances: Function, Fine Structure, Chemistry, and Physiology. Journal of Phycology 29:537-566.

Johnson RE, Tuchman NC, Peterson CG. 1997. Changes in the Vertical Microdistribution of Diatoms within a Developing Periphyton Mat. Journal of the North American Benthological Society 16:503-519.

Kaplan JB, Fine DH. 2002. Biofilm Dispersal of Neisseria subflava and Other Phylogenetically Diverse Oral Bacteria. Applied and Environmental Microbiology 68:4943-4950.

Krammer K, Lange-Bertalot H. 1991. Süßwasserflora von Mitteleuropa, Bacillariophyceae. Achnanthaceae. Kritische Ergänzungen zu Navicula (Lineolatae) und Gomphonema. Gustav Fischer Verlag, Stuttgart.

Lewin JC. 1955. The Capsule of the Diatom Navicula pelliculosa. Journal of General Microbiology 13:162-169.

Lubarsky HV, Hubas C, Chocholek M, Larson F, Manz W, Paterson DM, Gerbersdorf SU. 2010. The Stabilisation Potential of Individual and Mixed Assemblages of Natural Bacteria and Microalgae. PLoS ONE 5:e13794.

MacDonald JD. 1869. On the structure of the Diatomaceous frustule, and its genetic cycle. The Annals and Magazine of Natural History 3:1-8.

Mann DG. 1999. The species concept in diatoms. Phycologia 38:437-495. 
Mayama S, Kobayasi H. 1989. Sequential Valve Development in the Monoraphid Diatom Achnanthes minutissima Var. Saprophila. Diatom Research 4:111-117.

Molino PJ, Wetherbee R. 2008. The biology of biofouling diatoms and their role in the development of microbial slimes. Biofouling 24:365-379.

Morin S, Coste M, Hamilton PB. 2008. Scanning Electron Microscopy Observations of Deformities in Small Pennate Diatoms Exposed to High Cadmium Concentrations. Journal of Phycology 44:1512-1518.

Murdock JN, Dodds WK, Reffner JA, Wetzel DL. 2010. Measuring Cellular-Scale Nutrient Distribution in Algal Biofilms with Synchrotron Confocal Infrared Microspectroscopy. Spectroscopy 25:32-41.

Myklestad S, Holm-Hansen O, Vårum KM, Volcani BE. 1989. Rate of release of extracellular amino acids and carbohydrates from the marine diatom Chaetoceros affinis. Journal of Plankton Research 11:763-773.

Patrick R, Reimer CW. 1966. The diatoms of the United States. Academy of Natural Sciences.

Pfitzer E. 1871. Untersuchungen über Bau und Entwicklung der Bacillariaceen (Diatomaceen). University of Minnesota: Marcus.

Potapova M, Hamilton PB. 2007. Morphological and Ecological Variation Within the Achnanthidium minutissimum (bacillariophyceae) Species Complex. Journal of Phycology 43:561-575.

R Development Core Team. 2011. R: A language and environment for statistical computing. Vienna, Austria: R Foundation for Statistical Computing.

Round FE, Bukhtiyarova L. 1996. Four New Genera Based on Achnanthes (Achnanthidium) Together with a Re-Definition of Achnanthidium. Diatom Research 11:345-361.

Schlösser UG. 1994. SAG - Sammlung von Algenkulturen at the University of Göttingen Catalogue of Strains 1994. Botanica Acta 107:113-186.

Staats N, Stal LJ, Winder B de, Mur LR. 2000. Oxygenic photosynthesis as driving process in exopolysaccharide production of benthic diatoms. Marine Ecology Progress Series 193:261-269.

Stewart PS. 2003. Diffusion in Biofilms. Journal of Bacteriology 185:1485-1491.

Toyoda K, Idei M, Nagumo T, Tanaka J. 2005. Fine-structure of the vegetative frustule, perizonium and initial valve of Achnanthes yaquinensis (Bacillariophyta). European Journal of Phycology 40:269-279.

Toyoda K, Williams DM, Tanaka J, Nagumo T. 2006. Morphological investigations of the frustule, perizonium and initial valves of the freshwater diatom Achnanthes crenulata Grunow (Bacillariophyceae). Phycological Research 54:173-182.

Wang Y, Lu J, Mollet JC, Gretz MR, Hoagland KD. 1997. Extracellular Matrix Assembly in Diatoms (Bacillariophyceae) II. 2,6-Dichlorobenzonitrile Inhibition of Motility and Stalk Production in the Marine Diatom Achnanthes longipes. Plant Physiology 113:1071-1080.

Wang Y, Chen Y, Lavin C, Gretz MR. 2000. Extracellular matrix assembly in diatoms (Bacillariophyceae). IV. ultrastructure of Achnanthes longipes and Cymbella cistula as revealed by high-pressure freezing/freeze substituton and cryo-field emission scanning 
electron microscopy. Journal of Phycology 36:367-378.

Wetherbee R, Lind JL, Burke J, Quatrano RS. 1998. Minireview-The first kiss: Establishment and control of initial adhesion by raphid diatoms. Journal of Phycology 34:9-15.

Wickham H. 2009. ggplot2: Elegant Graphics for Data Analysis. Springer Science \& Business Media.

Widdows J, Brinsley M. 2002. Impact of biotic and abiotic processes on sediment dynamics and the consequences to the structure and functioning of the intertidal zone. Journal of Sea Research 48:143-156.

Willis A, Chiovitti A, Dugdale TM, Wetherbee R. 2013. Characterization of the extracellular matrix of Phaeodactylum tricornutum (Bacillariophyceae): structure, composition, and adhesive characteristics. Journal of Phycology 49:937-949.

Windler M, Leinweber K, Rio Bartulos C, Philipp B, Peter G. K. 2014a. Bacterial Influence on Diatoms from Photoautotrophic Freshwater Biofilms (Chapter 4: Biofilm and capsule formation of the diatom Achnanthidium minutissimum are strongly affected by a bacterium). University of Konstanz.

Windler M, Bova D, Kryvenda A, Straile D, Gruber A, Kroth PG. 2014b. Influence of bacteria on cell size development and morphology of cultivated diatoms. Phycological Research 62:269-281.

Windler M, Leinweber K, Rio Bartulos CR, Philipp B, Kroth P. 2015. Biofilm and Capsule Formation of the Diatom Achnanthidium minutissimum Are Affected by a Bacterium. Journal of Phycology.

Windler M, Gruber A, Kroth PG. 2012. Purification of benthic diatoms from associated bacteria using the antibiotic imipenem. Journal of Endocytobiosis and Cell Research 22:62 - 65.

Wustman BA, Lind J, Wetherbee R, Gretz MR. 1998. Extracellular Matrix Assembly in Diatoms (Bacillariophyceae) III. Organization of Fucoglucuronogalactans within the Adhesive Stalks of Achnanthes longipes. Plant Physiology 116:1431-1441. 


\section{1}

Crystal violet (CV) stained capsules (grey ovals) in xenic $A$. minutissimum biofilm (scale bar: $20 \mu \mathrm{m})$.

Micrograph depicts 11 days old culture and is a merge of the chlorophyll fluorescence channel (red; indicating diatom cells) and the bright-field image (grey). Some mature capsules are marked with arrows. Bright spots within diatom cells are lipid bodies. Bacteria are visible as light and dark speckles around and in between the diatom cells.

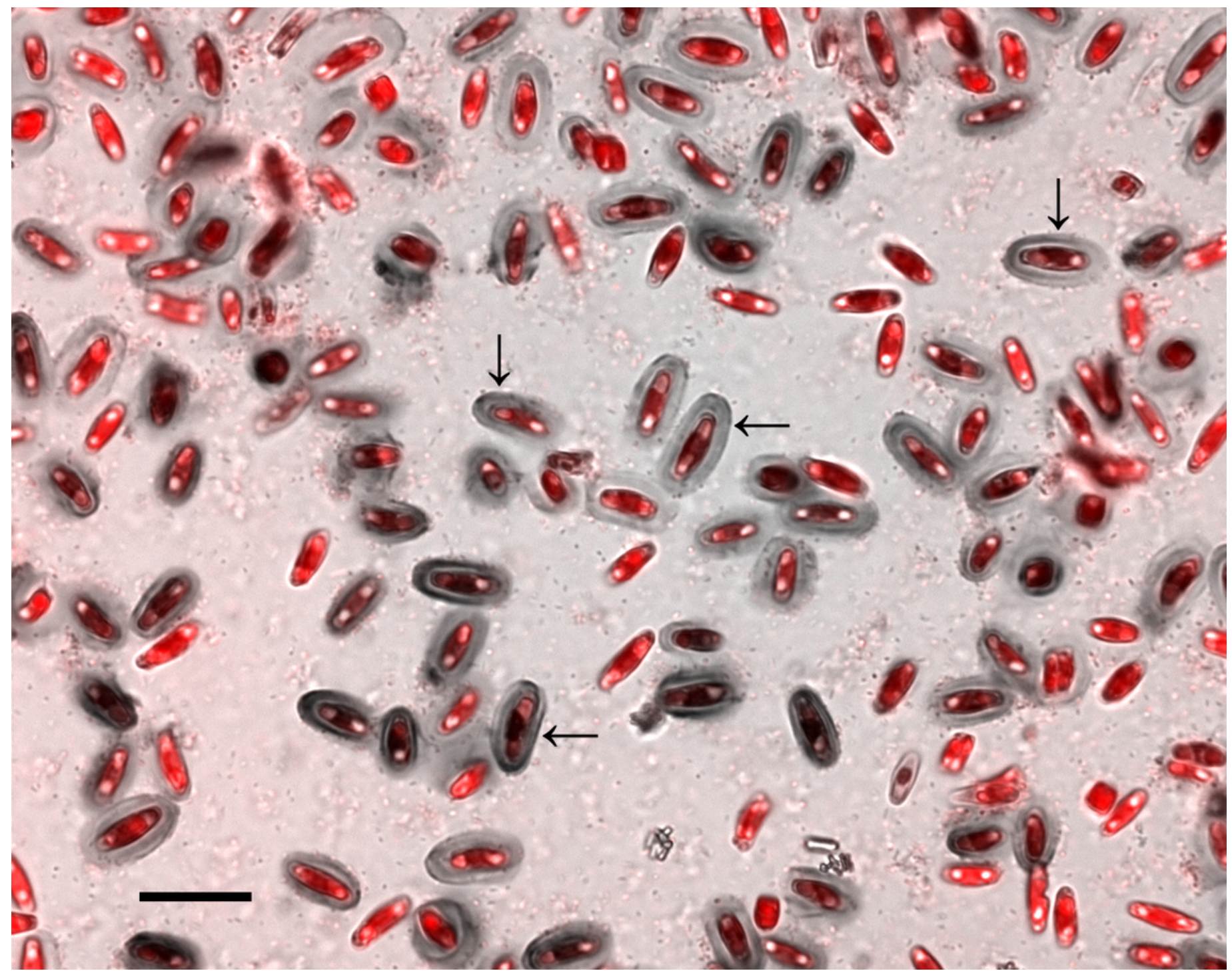




\section{2}

Identification of $A$. minutissimum capsules (asterisks) by subsequent observation of cell clusters by both bright-field and scanning electron microscopy of xenic biofilm (scale bars: $5 \mu \mathrm{m})$.

A: Bright-field micrograph of crystal violet (CV) stained, 31 days old culture. Encapsulated cells (asterisks) are strongly stained, while weak staining indicates few extracellular polymeric substances (EPS) on the frustule surfaces. B: Scanning electron micrograph of the the same cell cluster. Encapsulated cells (asterisks) are surrounded by an opaque material. Frustule pores are visible on cells that did not possess a capsule in the hydrated biofilm. Note also the unequal distribution of bacteria cells on capsules versus non-encapsulated frustules.
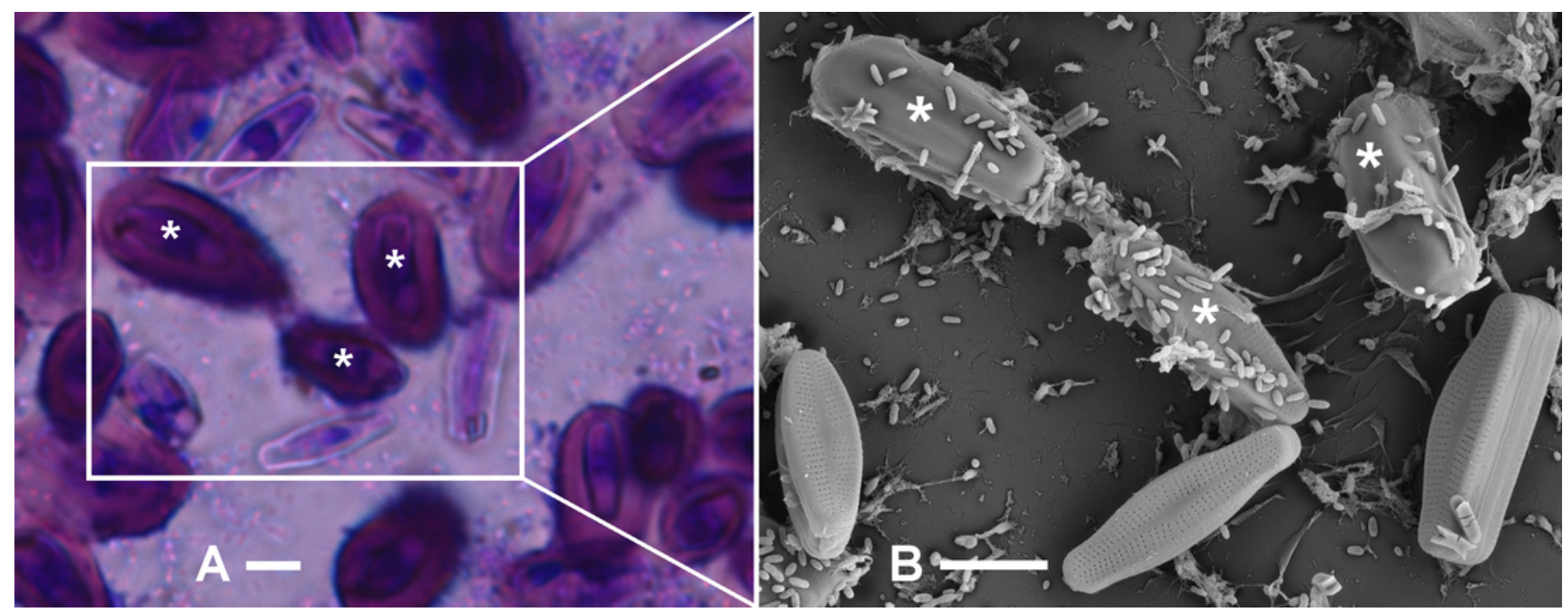


\section{3}

Comparison of microstructures on A. minutissimum cell surfaces in a xenic biofilm.

A (scale bar: $2 \mu \mathrm{m}$ ): Capsule material is sometimes stretched between cells and/or towards the substrate (arrows). Culture was 11 days old at the time of fixation for SEM. Asterisks denote magnified areas B and C. B (scale bar: $1 \mu \mathrm{m}$ ): Non-encapsulated cells possess a fibrillar mesh of varying degrees of density. Frustule pores are only partially covered and in some cases, fibrils stick out from the frustule. C (scale bar: $1 \mu \mathrm{m}$ ): Encapsulated cells are completely covered with a material of slightly granular structure, but lacking clearly discernible features.
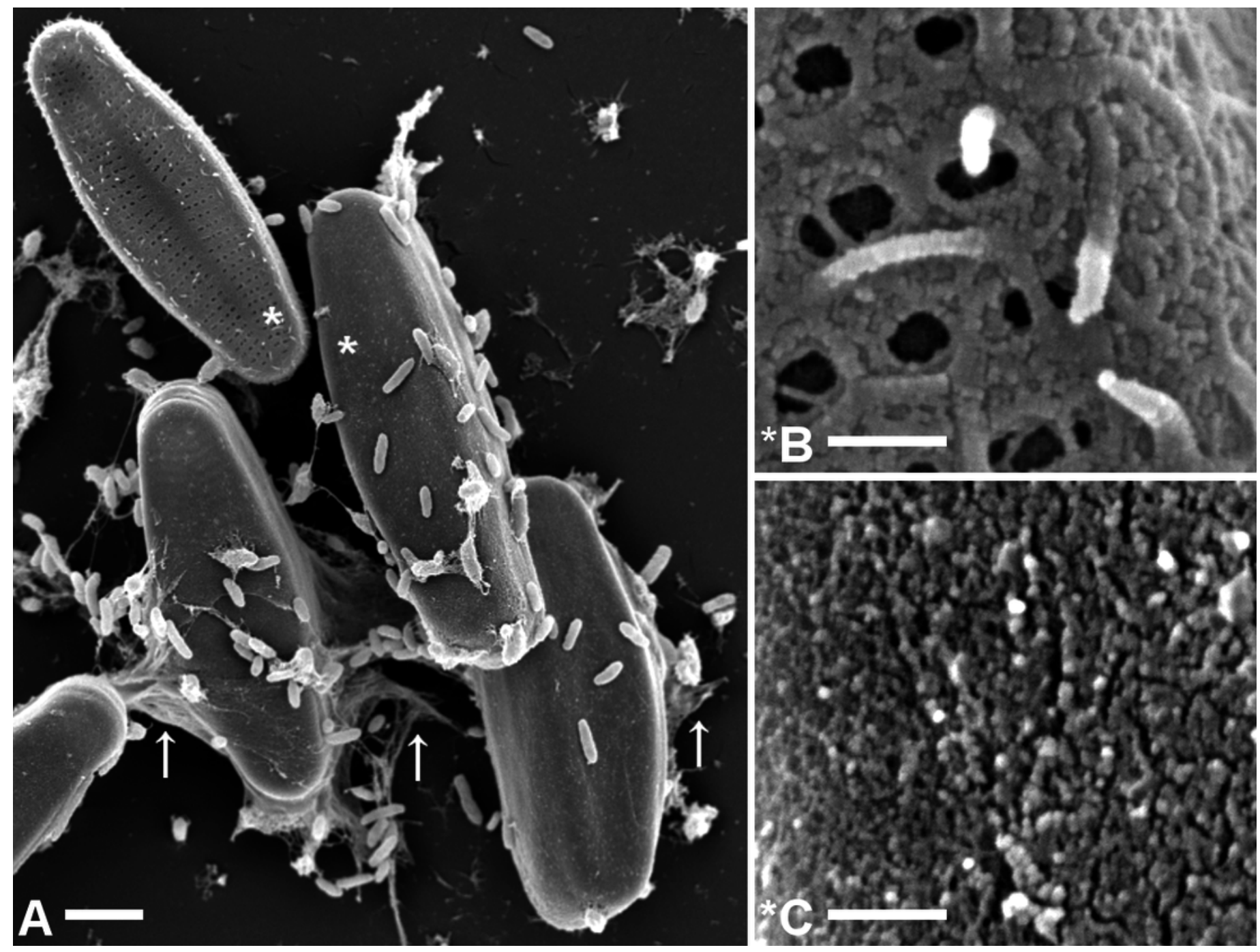
4

Scanning electron micrographs of terminal parts of $A$. minutissimum cells at potentially different encapsulation stages of xenic biofilms (scale bars: $1 \mu \mathrm{m}$ ).

Fibrillar meshes (A) may form capsule material (C) by denser growth and cross-linking of fibrils (B). Depicted samples were taken from stationary, 11 to 31 days old cultures.

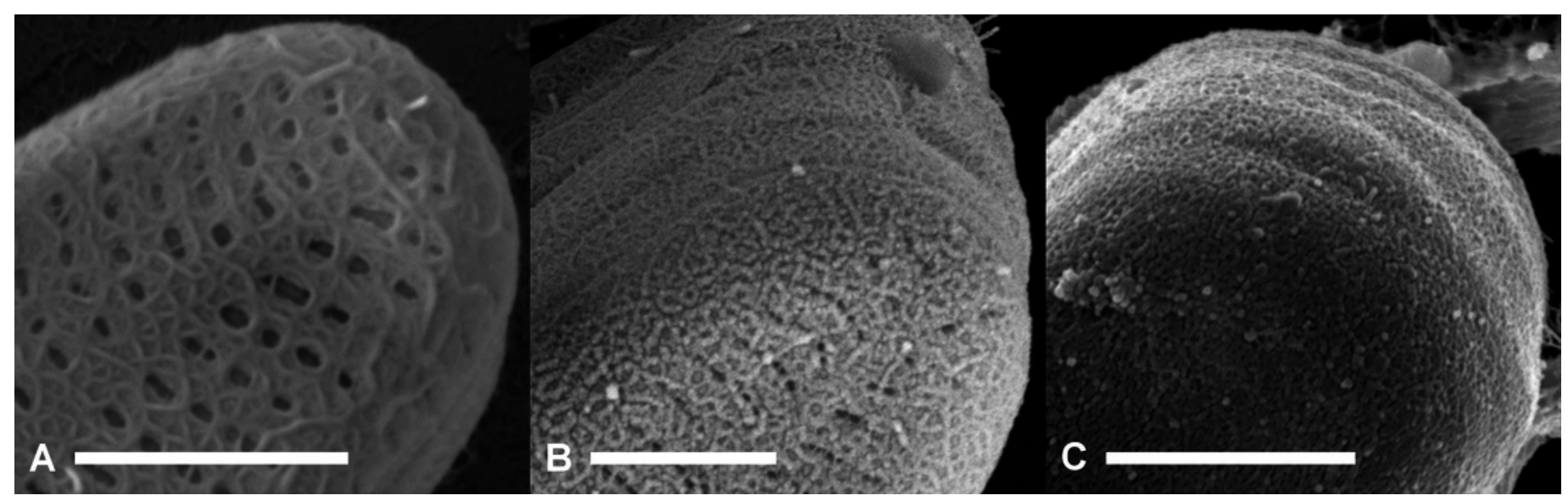




\section{5}

Fibrillar microstructures (arrow pairs) within capsule material of $A$. minutissimum cells in xenic biofilm are revealed by mechanical stress (scale bars $=1 \mu \mathrm{m}$ ).

Micrographs depict samples from an 11 days old culture. A: Tip of a partially encapsulated cell. Fibrillar substructures are continuous throughout the capsule material. B: Capsule material stretched between cells frays into fibrils.
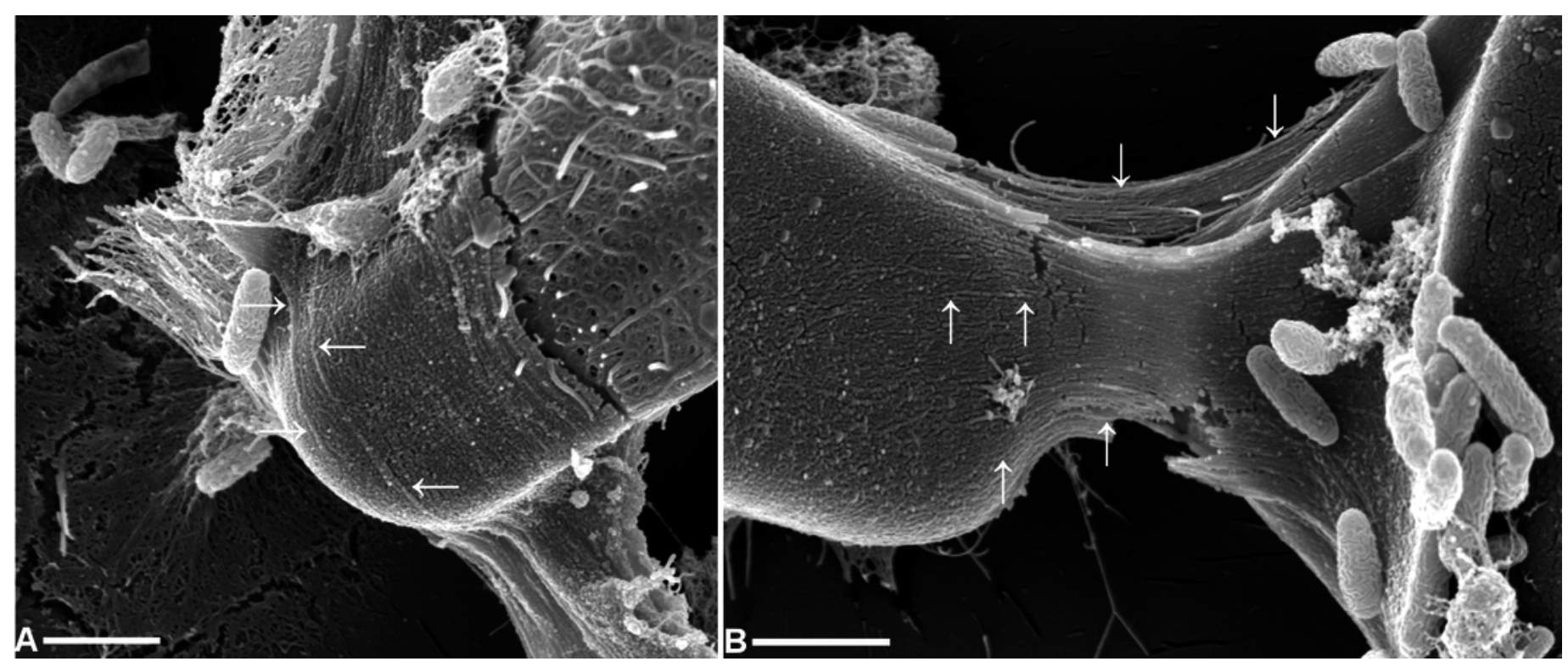


\section{6}

Capsule material in xenic $A$. minutissimum biofilms does not contain silicon and can thus be distinguished from the frustule.

Samples were taken from 11 days old culture. A: Scanning electron micrograph of capsule material that is stretched between $A$. minutissimum cells (partially visible). Labels indicate energy-dispersive X-ray (EDX) measurement points. B: EDX spectra show that less silicon (peak around $1.75 \mathrm{keV}$, with grey background) is found in the capsule material without cell body below it (black trace) compared to the control points on the cell bodies (blue and turquoise traces). Stronger Au signal around $2.15 \mathrm{keV}$ likely results from larger goldsputtered surface area in close proximity to the "capsule" measurement point. 

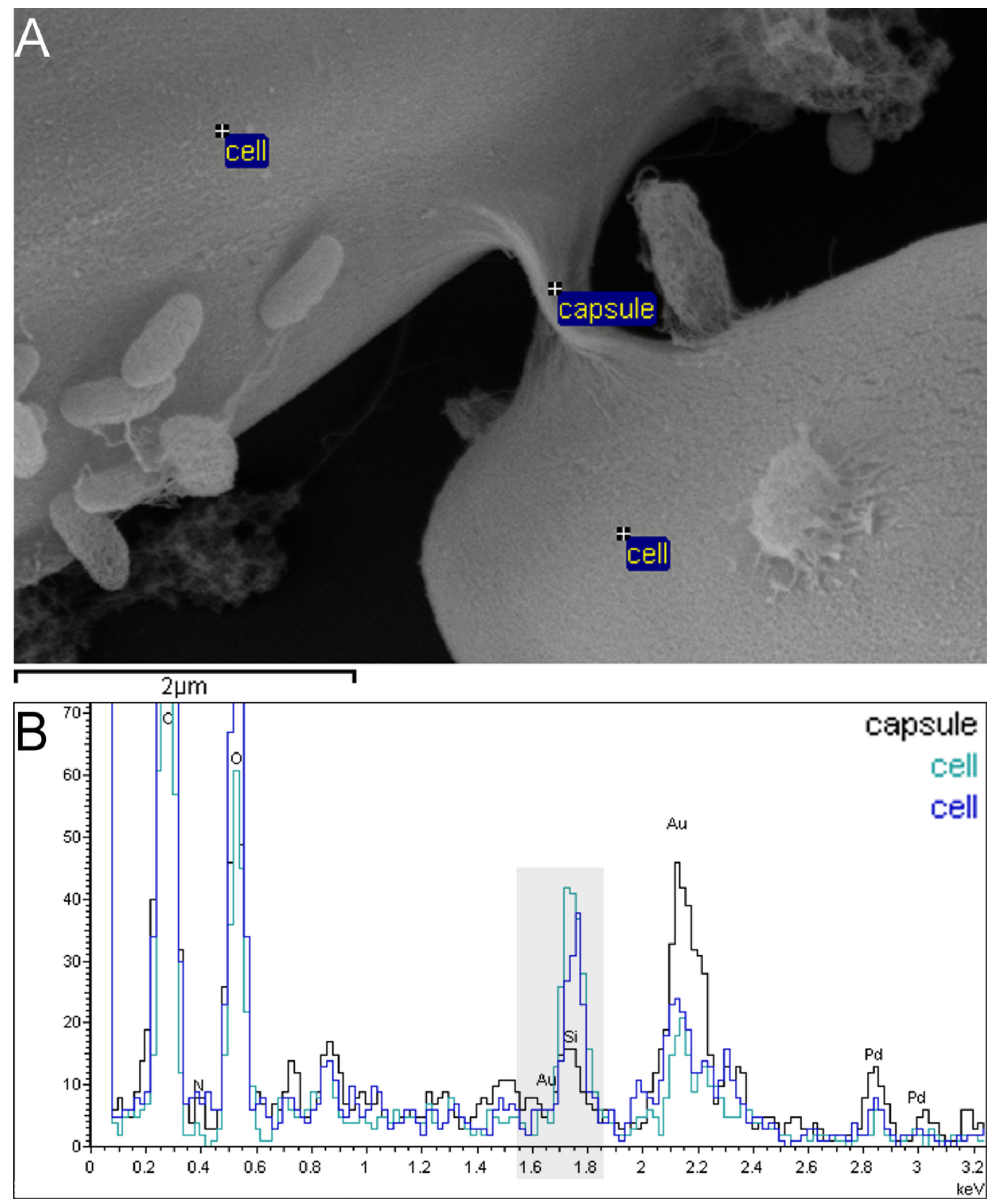


\section{7}

Distribution of the number of bacteria cells adherent to diatom valve faces of different surface types (frustule or capsule) in xenic $A$. minutissimum biofilms.

Bacteria were counted in SEM images, if they were in direct, visible contact with the valve face of either a frustule ( $N=54)$ or a completely encapsulated diatom cell $(N=71$; see figures $2 \mathrm{~B}$ and $3 \mathrm{~A}$ for illustration). Samples were taken from 11 to 31 days old cultures. Boxes represent 1st and 3rd quartile. Black center lines represent medians. Whiskers extend to 1.5 -fold of the inter-quartile range. Diamond symbols represent means. Black dots are outliers.

adherent to frustules

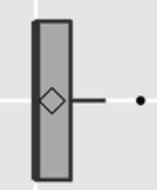

adherent to capsules

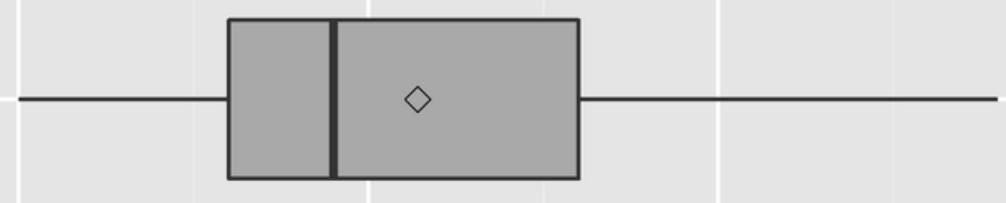

0 10

20

bacteria cells per diatom
30

40 